\title{
From Charlemagne to the Commercial Revolution (c.80o-1150)
}

\author{
Andrew R. Woods
}

Relatively few general works in English cover money in the period between the 8 th and 12th centuries. Perhaps unsurprisingly, the further east and south within Europe one goes, the less accessible scholarship there is in English or other major Western European languages. In general terms, the production of coinage is reasonably well served, with general works providing a broad overview of when, where, and by whom it was struck. For readers completely unused to coinage, there is a good general survey by Philip Grierson, who introduces the subject on a century-by-century basis. ${ }^{1}$ For the first half of the period covered by this chapter, Grierson and Mark Blackburn's Medieval European Coinage still provides the best overview of European coinage to the 1oth century. ${ }^{2}$

For those more interested in how money was used across Europe - when, where and by whom - there are greater challenges. The second half of the period is very well served by Peter Spufford's contributions to the subject, which provide an approachable and broad analysis of money. ${ }^{3}$ However, understanding the use of money for much of the period rests upon the interpretation of archaeological material: hoards, excavated coins, and single-finds. Here, the student of money runs into the challenges of modern international borders, as every country across Europe has differing approaches to its archaeological heritage. A clear example is attitudes to the use of metal-detectors, with countries such as England and the Netherlands permitting use and creating systems to record the thousands of finds that result. This is a contrast to most other areas, where it is banned, restricted or varies on a regional basis. This can lead to imbalances of evidence; there are, for example, nearly 50 times as many single-coin finds reported from England, where detecting is legal, as from Ireland, where it is not. ${ }^{4}$ This type of imbalance has the potential to mislead when

Grierson, The Coins of Medieval Europe.

2 Grierson and Blackburn, Medieval European Coinage.

3 Spufford, Money and Its Use in Medieval Europe.

4 Comparing figures from Naismith, "The English monetary economy," and Woods, "Monetary activity in Viking-age Ireland". 
we consider how coinage was used across the modern political boundaries of Europe. This has led to archaeological studies which have tended to be more regionally specific, with relatively few attempts to draw together an understanding of how money was used at a more general level. ${ }^{5}$

\section{The Triumph of the Penny}

The story of money between about 800 and 1150 in Europe is intimately connected to the adoption and adaptation of the silver denier, or penny. ${ }^{6}$ Following its creation in Francia in the mid-8th century the denomination became dominant across Europe over a course of centuries. However, how it was administered and used, and what it replaced, varied enormously across this period and the differing areas where it came to be used.

At the eve of the penny, a variety of coinages existed within Europe, reflecting both the fragmentary political units of the period and a variety of external influences. Gold was struck across southern Europe; in those areas with Byzantine connections, there were also silver and copper coinages. ${ }^{7}$ Across Northern Europe, the coinage was silver, quite thick with a small diameter, typically $c .11 \mathrm{~mm}$. Francia's coins are typically referred to as deniers while those of England, the Low Countries, and Denmark are often described as sceattas. ${ }^{8}$ The pre-existing patterns of currency were fundamentally altered by the gradual adoption by Carolingian rulers of broad, thin silver coins between $75^{1}$ and $840 .{ }^{9}$ Charlemagne was at the heart of these changes. The monetary system he created, described as a "single European currency", replaced the variety that had existed previously. ${ }^{10}$ The reforms he enacted, which were continued by his 9th-century successors, altered almost every aspect of the coinage.

Carolingian changes entrenched the dominance of silver, consolidating it as the only significant metal means of exchange. Gold coinage was largely abandoned, assuming an almost entirely symbolic role. ${ }^{11}$ This Northern European

5 A notable exception is a recent volume which brings together a range of case-studies: Gelichi and Hodges (eds.), From One Sea to Another.

6 The terms "denier" and "penny" refer to the same form of coin. Penny will be used for simplicity.

7 Grierson and Blackburn, Medieval European Coinage, pp. 55-72; Grierson, The Coins of Medieval Europe, pp. 30-32.

8 Grierson and Blackburn, Medieval European Coinage, pp. 138-89.

9 Ibid., pp. 190-217.

10 Coupland, "Charlemagne's coinage", p. 211.

11 Blackburn, "Gold in England". 
pattern gradually extended south, with the gold coinages of kingdoms in the southern parts of the empire largely eliminated in favour of silver. ${ }^{12}$ The smallmodule silver coins of northern Europe were also dispensed with, with the Carolingian rulers instead issuing broad, thin deniers. While some of these changes began under Pepin the Short, they were taken a stage further by his successor, Charlemagne. The weight of the coinage was increased to $c .1 .3 \mathrm{~g}$ and the flan size to $c .20 \mathrm{~mm}$, with a corresponding drop in thickness. ${ }^{13}$ The ratio of 240 pennies to the pound begun by his predecessors was entrenched and would become the standard across Europe for hundreds of years.

The increase in coin size may seem a minor technical aspect, but it had revolutionary effects, allowing for larger and more elaborate imagery as well as for more extensive legends. These had huge implications for both the administration and the iconographic potential of coinage. The small silver coins which preceded the Carolingian pennies incorporate a great deal of iconographic variety which has been extensively explored, with powerful results. ${ }^{14}$ However, it would appear that one of the motivations behind the striking of the larger pennies was the desire to incorporate more onto each face of the coin. On the Carolingian coins, there were clear moves to incorporate more overt indications of royal authority. This began with Pepin in the 750 os when the contracted Latin legends RP (Rex Pipinus) and RF (Rex Francorum, King of the Franks) were included (Figure 5.1). ${ }^{15}$ The consistency of the legends is very noticeable in Charlemagne's reign, with the various Frankish mints rendering it in the form CAROLVS, replacing the numerous forms that had existed previously. Following further reform in 793-794, there was even greater consistency, with a cross and the royal title in the form +CARLVS REX FR on the obverse and the name of the mint surrounding the royal monogram on the reverse. ${ }^{16}$ This coinage could circulate across the vast territories of the Carolingian empire. ${ }^{17}$

The trend was not just towards consistency but also exploiting the iconographic possibilities that coinage offered. As discussed below, coinage represented one of the only significant means of mass communication in the early medieval period, a possibility which offered much to bolster the authority of medieval rulers. This is very apparent on the coins struck late within Charlemagne's reign, where he is depicted in Roman imperial garb with the legend

\footnotetext{
12 Grierson and Blackburn, Medieval European Coinage, p. 206.

13 Grierson, The Coins of Medieval Europe, p. 34; Coupland, "Charlemagne's coinage”, p. 211.

14 Gannon, The Iconography of Early Anglo-Saxon Coinage.

15 Grierson, The Coins of Medieval Europe, p. 34.

16 Ibid., pp. 34-35.

17 Coupland, “Charlemagne's coinage”, p. 211.
} 
WOODS
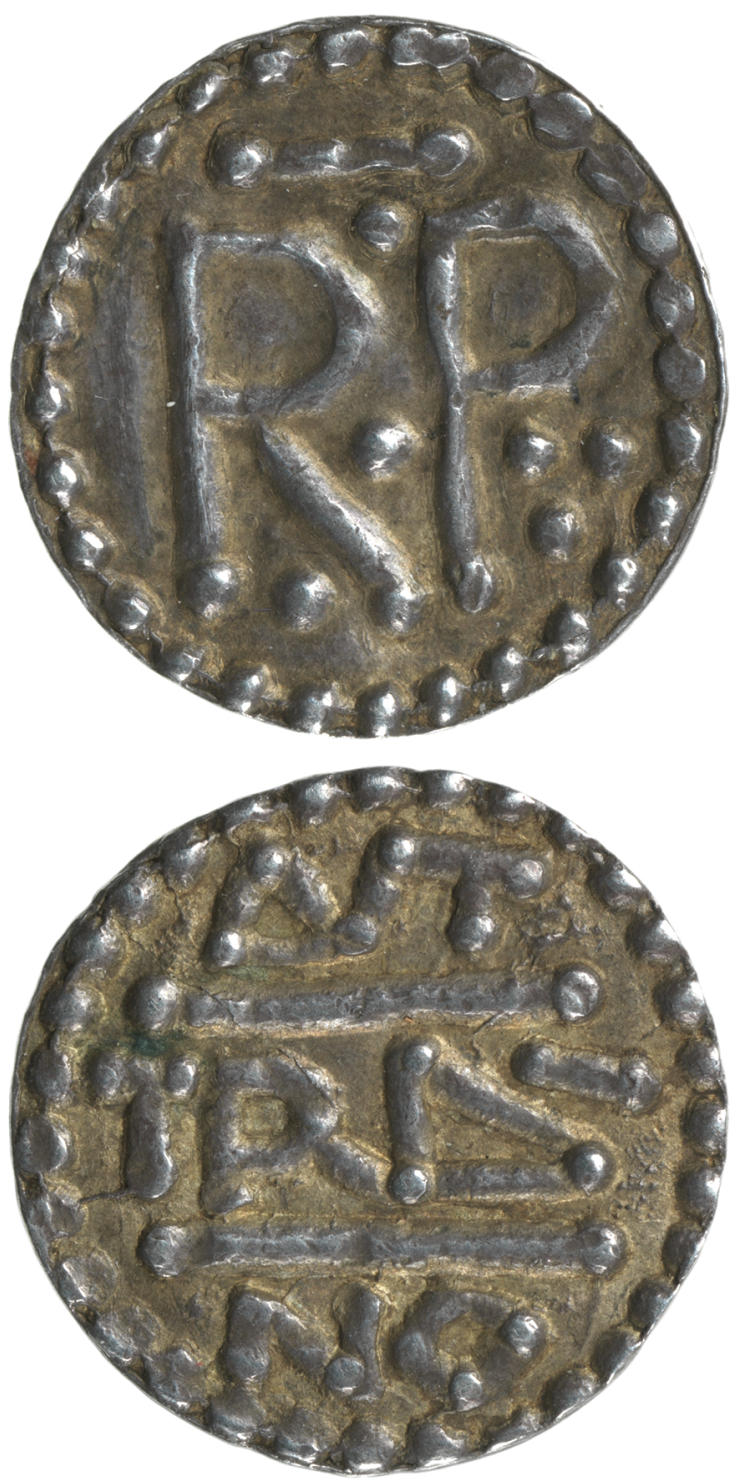

FIGURE 5.1 Silver denier of Pepin the Short. CM.PG.8988-2006. SOURCE: (CTHE FITZWILLIAM MUSEUM, CAMBRIDGE. 
KAROLVS IMP [erator] AVG [ustus]. A broad range of imagery exploited by later Carolingian rulers added monograms, busts, crosses, and temples to bolster royal authority. ${ }^{18}$

The Carolingian coinage was not produced in a single mint, but at many places across the empire. In a pattern common across Europe, the Latin name of the mint town and/or the name of the moneyer (monetarius) was included on the coins themselves. It is important to recognize that the monetaria were likely to be high-status individuals responsible for overseeing the production of coinage rather than those physically striking the coins. While both mints and moneyers had occasionally been named on coins before the advent of the penny, the new coinage made this a much more consistent feature. Nearly one hundred mints have been identified on Carolingian coinage, although many were only small or temporary. ${ }^{19}$ The major mints were at Melle and Dorestad, and they serve to emphasize the point that silver was minted at the places where it was needed. Dorestad was a major port, where foreign silver would be expected in quantity and which provided the raw material for the striking of coinage. Similarly, the mint at Melle was close to the largest silver mines in Europe.

Carolingian coinage reforms also demonstrate that alongside quite precise mechanisms for the production of coinage there were also rules in place to prohibit the use of other coinages. This is most clearly articulated in Charles the Bald's Edict of Pîtres, issued in 864, which recorded that only the "new money" (novae monetae) was to circulate in his kingdom, replacing the varied currency that had come before. ${ }^{20}$ This edict articulated two major policies: the exclusion of "foreign" currency and the renewal of older types of coinage. In the case of the former, it would appear that steps were actively pursued to ensure that currency from beyond the boundaries of a kingdom was not allowed to circulate within it. ${ }^{21}$ This is represented in contemporary hoards, where only currency from within the kingdom is present. The second aim of the Edict of Pîtres saw the "renewal" of coinage, often referred to as renovatio monetae. ${ }^{22}$ This can be conceptualized in a similar manner to the introduction of the Euro: older types were removed from circulation, leaving only the current and

18 Garipzanov, "The image of authority in Carolingian coinage"; Biddle, "XPICTIANA RELIGIO and the tomb of Christ"; Coupland, "The portrait coinage of Charlemagne".

19 Coupland, "Charlemagne's coinage", pp. 214-15.

$20 \quad$ Grierson, "The gratia dei rex coinage of Charles the Bald"; Naismith, Money and Power in Anglo-Saxon England, p. 181.

21 See Coupland, "Money and coinage under Louis the Pious".

22 Cf. Grierson, "Numismatics and the historian", p. x. 
new type. This process created profits for both the issuing authority and moneyers. That this was successfully achieved during the Carolingian period can be seen in the large hoards from Apremont-Veuillin and Belvézet, both of which contain almost exclusively coins of the type then current. ${ }^{23}$ The ability to demonetize older types was seldom achieved across the early medieval period but can be detected at a number of points, particularly where the hoard record indicates that only one type of coinage was circulating.

Charlemagne and his successors created a silver coinage, the penny, which came to dominate Europe. Across most of Europe this was as a fairly direct result of Carolingian control, but in England, beyond Charlemagne's power, the penny also became the dominant currency of the time. Offa, head of the largest kingdom within England, seized upon its symbolic potential. ${ }^{24}$ By the middle of the gth century only the slightly anomalous coinage of the kingdom of Northumbria in northern England continued to be manufactured using the older, smaller module. ${ }^{25}$

While the form of the coinage that would eventually cover much of Europe looked fundamentally similar to that created by Charlemagne, it is important to acknowledge that the way silver pennies were made, administered, and used varied significantly. The administrative control exhibited on Carolingian coins - with consistent types, excluded foreign currency, and well-maintained weight and fineness - was not achieved consistently elsewhere. The symbolic aspects of the coinage, reinforcing a powerful royal authority, are also relatively seldom found elsewhere in this period. Even more unusual was successful renovatio monetae, which was only infrequently achieved across much of Europe. While a high-quality silver coinage with a well-maintained weight standard produced for a strong ruler, backed by an efficient administration, and deploying imagery which bolstered royal authority can certainly be claimed for Carolingian Francia and Anglo-Saxon England, it remained an unusual occurrence for most of this period.

Furthermore, there remained areas which did not embrace the use of the large silver penny in any significant way. At the southern edge of the empire, and in areas with Byzantine and Arab influence, other coinages persisted. These were issued in a variety of metals, as can be seen in Southern Italy, where several different coinages were used. ${ }^{26}$ Furthermore, a relatively widespread

\footnotetext{
23 Coupland, "Money and coinage under Louis the Pious", p. 32.

24 Naismith, "Kingship and learning".

25 Metcalf, "Introduction".

26 Rovelli, "Some considerations"; Blackburn "Money and coinage", 539-44; Rovelli, "Coins and trade in early medieval Italy".
} 
monetary economy did not respond well to the fairly high-value silver penny, with silver and copper-alloy coins of lower fineness persisting in several regions. ${ }^{27}$ Gold, struck at a number of mints and from a significant number of dies, also continued to play a greater role in Italy than in areas further to the north. ${ }^{28}$ The Italian peninsula is an excellent case-study of a region where a number of different monies in different metals were used, reflecting both its complex history and links to other parts of the Mediterranean and north of the Alps. This example serves a reminder that caution must be exercised regarding generalizations.

\section{New Boundaries}

One of the clearest trends during this period was coinage produced and used across many new areas of Europe. It was at this time that significant areas beyond the old boundaries of the Roman Empire began to utilize silver coinage as a major means of exchange. Where the preceding centuries had largely seen coinage reintroduced to places where it had existed previously, between the 9th and 11th centuries it expanded beyond these boundaries. Eastern Europe, Ireland, and much of Scandinavia all saw coinage struck and used on a significant scale for the first time. While noting this, it is important to distinguish between the chronology of production and use in these areas, as the two seldom occurred simultaneously. In most areas where coinage was a novel phenomenon, the use of silver led the way, with production following thereafter.

In Scandinavia, where evidence for the expansion is most clear, coinage was known in small quantities in the 8th and gth centuries, with mints at Ribe and Hedeby. ${ }^{29}$ Both produced only small quantities of coinage and it appears that this did not penetrate far beyond the hinterlands of the two towns. ${ }^{30}$ The use of silver as a means of exchange became increasingly common during the course of the 9th and 1oth centuries. ${ }^{31}$ However, this was seldom in the form of whole coins, with silver much more commonly found in the form of bullion,

27 Rovelli, "Some considerations", 208-11.

28 Rovelli, "Some considerations", 218-20; Blackburn, "Money and coinage", 541-43.

29 Wiechmann, "Hedeby and its hinterland"; Malmer, "South Scandinavian coinage in the ninth century".

$30 \quad H e i j n e$, "Viking-age coin finds from south Scandinavia"; Hilberg, "Silver economies".

31 A summary of this, including a chronological framework, is provided in Williams, "Silver economies, monetisation and society". 
valued according to its weight. ${ }^{32}$ The precise mechanics - when, where, and why - of how weighed silver came to be used as a means of exchange are complex, with enormous variation across Scandinavia. ${ }^{33}$

In the early part of the 9th century, small numbers of coins were imported into Scandinavia from both the East and the West. ${ }^{34}$ However, these were only a tiny part of the means of exchange. In Norway, only 2 per cent of the total volume of silver found in hoards from before 900 was in coined form. ${ }^{35}$ The form that this silver took varied enormously, being composed of a mix of objects, frequently jewellery and ingots. These could be whole or fragmented, as could the coins that they were found alongside. The Spillings hoard, which has been described as the "largest Viking-Age silver hoard", gives a sense of the types of material that can be found mixed together (Figure 5.2). ${ }^{36}$ Weighing $67 \mathrm{~kg}$, it contains 486 arm rings, 25 finger rings, and 8 o ingots, as well as over 14,000 coins. The coinage is highly fragmentary, suggesting it was valued for its weight, while many of the arm rings have lost their display function, having been squashed together to form consistent units of $c .200 \mathrm{~g}$ weight. ${ }^{37}$ The hoard highlights the importance of the bullion or weight value ascribed to silver in the period and also the manner in which it was frequently transformed from one form to another.

The coins in the Spillings hoard were overwhelmingly dirhams imported from the Arabic Caliphate. Beginning around 800 a small trickle of silver coins flowed up the Russian and Ukrainian river systems into the eastern parts of the Baltic. ${ }^{38}$ The gradual expansion in the use of Arabic silver is usually analysed through a consideration of hoards, with these dated by their terminus post quem, the date of production of their latest coin. There are difficulties with this methodology, as it is uncertain how quickly the coins travelled from the mints of the Near East to Scandinavia. This could be a relatively speedy process: the last dirham lost at Torksey in England was struck in the mid-86os and likely deposited in $872-873$, a gap of only six or seven years to cover several thousand miles. ${ }^{39}$ In other cases, coins could remain in circulation for very long periods

32 There is a very extensive literature considering the use of weighed silver; see Skre, Means of Exchange; Graham-Campbell, Sindbæk, and Williams, Silver Economies.

33 Hårdh, Silver in the Viking Age.

34 Blackburn, "The coin finds", pp. 56-58; Kilger, "Kaupang from afar", pp. 211-21.

35 Gullbekk, Pengevesenets fremvekst, p. 32.

36 Ostergren, "The Spillings hoard(s)".

37 Ibid., pp. $327-28$.

38 Kilger, "Kaupang from afar", pp. 211-21; and Bogucki, "The beginning of dirham import".

39 Blackburn, "The Viking winter camp at Torksey". 


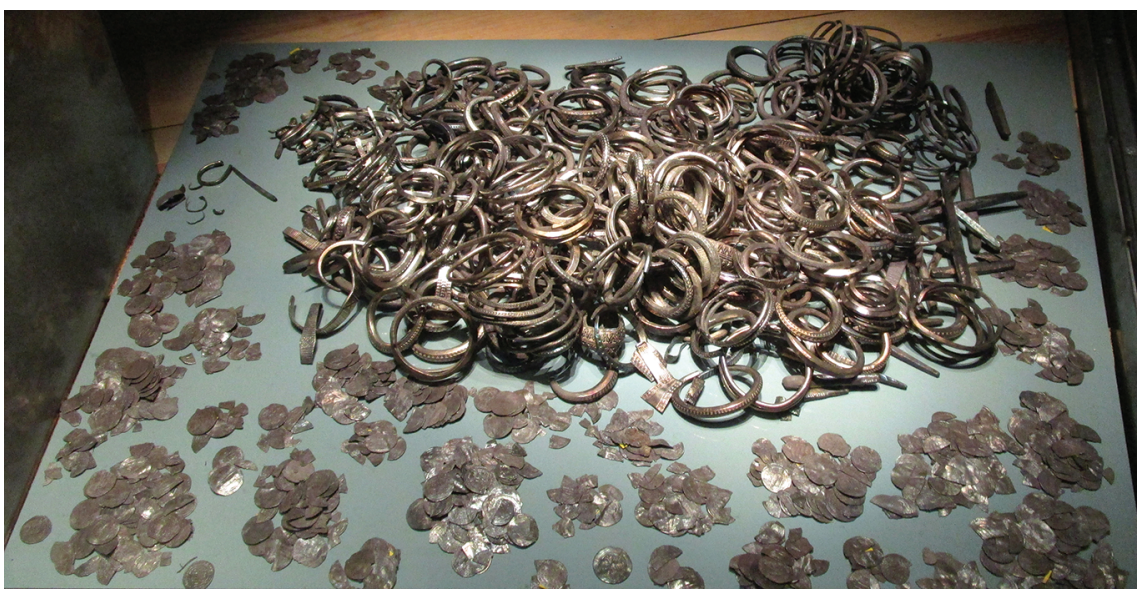

FIGURE 5.2 The Spillings hoard.

SOURCE: (CGÖRAN STRÖM, GOTLAND MUSEUM.

after they were struck, further complicating judgements about the chronology of their circulation..$^{40}$

During the course of the gth century the volume of silver dirhams, struck for the rulers of the Abbasid Caliphate, in use in Scandinavia increased. These were not found evenly across the whole of the region, but are more common in areas which display some characteristics of towns or central places. Ribe, Uppakra, Birka, and Kaupang all have evidence for coin use in this period, often substantially earlier than their hinterlands. ${ }^{41}$ The only major exception to this is on the island of Gotland, where silver hoards from an early date have been found in rural areas. It has been argued that these may represent the money of traders engaged in exchange in the Russian rivers, concealed in a domestic setting. ${ }^{42}$ In more general terms, the volume of coin finds from the latter part of the century is far greater than the earlier, suggesting that the flow of silver into Scandinavia increased and also that its use as a means of exchange became more common.

The hoards show a brief break in the supply of silver in the late 9 th century, before the flow from the East became a flood in the early part of the 1oth century. ${ }^{43}$ Coins struck for the Samanid Caliphate (892 onwards) are found in very large numbers across Scandinavia; the number of hoards and the volume

40 Cf. Blackburn, "The coin finds", pp. 38-47.

41 Heijne, "Viking-Age coin finds from south Scandinavia"; Gustin, "Coin stock and coin circulation in Birka"; and Blackburn, "The coin finds".

42 Skre, "Commodity money", pp. 84-85.

43 Gustin, "Coin stock and coin circulation in Birka", pp. 238-39; and Jonsson, "Sweden in the tenth century”, pp. 249-54. 
of coins that they contain both increased significantly. ${ }^{44}$ There was also a corresponding decrease in the importance of other forms of silver. ${ }^{45}$ The distribution of the hoards is much more varied than in previous periods, with the use of silver becoming more common in rural areas, beyond the towns which had dominated its use during the course of the gth century. ${ }^{46}$

The large volume of silver, valued according to weight, circulating in Scandinavia required specialized equipment to ensure that the correct amounts were measured out. Bullion weights were placed on the scale pan of a balance with the corresponding amount of silver measured out thereafter. Some of these weights were of a relatively standardized form and were possibly related to those used in the Near East, the source of the dirhams that made up many of the transactions. ${ }^{47}$ Corresponding with a desire to ensure that the correct weight was achieved was a requirement for the right purity of silver. Testing occurred in a number of ways, including edge-nicking and pecking, where a knife is used to lift a small section of the silver surface to check its hardness. ${ }^{48}$ This was likely to have been reasonably accurate if undertaken by a skilled person. Testing of this sort appears to have occurred primarily when there were silvers of differing purities circulating alongside one another.

If the period to 95o had seen the majority of silver in Scandinavia take the form of bullion, then the following century saw a gradual transformation of money. The relative importance of bullion decreased greatly such that in 11th-century Norway the majority of silver was in the form of whole coins. ${ }^{49}$ Similar patterns can be discerned in other parts of Scandinavia, with Cecilia von Heijne noting neatly that at the very end of the 1oth century coins begin to dominate and "Generally speaking, the older a hoard is, the higher the percentage of its contents consisted of non-monetary items".50

Towards the end of the 1oth century and into the early years of the 11th, the circulating currency of Scandinavia came to be dominated by coins from England and Germany. This is very clear from the hoards, where a majority are imported silver pennies, with the relative proportions of English and German silver varying depending on the hoard's geographic

\footnotetext{
44 Heijne, "Viking-Age coin finds", pp. 19o-91.

45 Ibid., p. 191; and Gullbekk, Pengevesenets fremvekst, p. 32.

46 Heijne, "Viking-Age coin finds", p. 199.

47 Kilger, "Hack-silver, weights and coinage", pp. 264-66.

48 Moesgaard, "Grisebjerggård hoard".

49 Coinage made up 9 per cent of Norwegian silver in the period 9oo-95o and 84 per cent in the period 1050-1100: Gullbekk, Pengevesenets fremvekst, p. 32.

$5^{\circ}$ Heijne, "Viking-Age coin finds", p. 191.
} 
location. ${ }^{51}$ How the large number of coins made their way to Scandinavia has been a matter of some debate. ${ }^{52}$ The inflow of currency coincides broadly with the historically attested payments of "gelds" in England. These were used as a way of dissuading prospective raiders, with large payments recorded in the years 991, 994, 1002, 1007, 1012, and 1018. There were also regular "Heregeld" payments levied in England to pay for Scandinavian mercenaries until $1051 .{ }^{53}$ The extent to which the large numbers of coins found in Scandinavia represent these political geld payments or underlying trade, and the routes by which they reached the region, are still contested.

What can be stated with a greater degree of certainty is that imported English currency provided the iconographic models for the "royal" coinages struck in the 99os in the kingdoms of Denmark, Sweden, and Norway. ${ }^{54}$ In each instance, the coinage imitated English designs but included the local king's name: Sven Forkbeard in Denmark, Olof Skötkonung in Sweden, and Olaf Tryggvason in Norway. Their success varied somewhat: royal coinage proved longest-lived and most significant in Denmark, abortive after a strong beginning in Sweden, and slow-starting in Norway. ${ }^{55}$ This likely reflects both the varying strength of royal power and the pre-existing patterns of coinage, which were strongest to the south. The "regal" coinages produced across Scandinavia in the 99os followed royal conversion; it has been argued that they were connected to the adoption of models of Roman Christian kingship. ${ }^{56}$ These emphasized a strong relationship between church and state, each working together to provide the structures for society. Coinage provided one such structure, legitimizing kingship and emphasizing Latin piety. In the case of the latter, it is notable that all the coins used Christian imagery and Latin legends.

The coinage issued in Scandinavia was not instantly accompanied by attempts to remove old and foreign currency from circulation. In all cases, the newly struck royal coinages circulated alongside older types which had previously dominated. In almost all hoards, locally struck coinage remained in the

$51 \quad$ Moesgaard, "The import of English coins to the northern lands", p. 392.

52 Ibid.; Metcalf, "Inflows of Anglo-Saxon and German coins"; Blackburn and Jonsson, "The Anglo-Saxon and Norman element of north European coin finds".

53 Moesgaard, "The import of English coins to the northern lands", p. 390.

54 Gullbekk, "Coinage and monetary economies", pp. 162-64; and Williams, "Kingship, Christianity, and coinage", pp. 190-96.

55 Skaare, Coins and Coinage in Viking-Age Norway; Jensen, Danish Coins from the nth Century; and Gullbekk, "Coinage and monetary economies", p. 162.

56 Williams, "Kingship, Christianity, and coinage" p. 206. 
minority for many decades. ${ }^{57}$ Attempts at the exclusion of foreign currency and the "renewal" of currency stock by forcing users to utilize the recent, official currency appear to have taken place only some time later. In Norway, this occurred during the reign of Harald Hardråde (1046-1066) and again under his son Olaf III. ${ }^{58}$ Similarly, in certain areas Danish coins only became the dominant medium several decades after they were first struck. ${ }^{59}$

The expansion of silver and coinage into new areas of Europe was not a simple or linear process, varying depending upon time and place. ${ }^{60}$ However, it is possible to draw some broad trends from the Scandinavian example. First, the use of silver in an economic context was almost always initially in its weighed form. Bullion led the way across Scandinavia and remained dominant for decades or even centuries. Similar patterns can be observed in other areas with little previous history of economic use of silver, such as Ireland and Slavicspeaking areas of the south Baltic. ${ }^{61}$ The use of silver as money appears to have been catalyzed by a relatively small number of sites such as Kaupang, Ribe and Birka, which show evidence for its earliest use. The extent to which these places represent "towns" and the importance of long-distance trade in this process is a matter of some debate, but it is clear that they had a very important role in the adoption of silver as money. ${ }^{62}$ Following initial use at a relatively small number of sites, the trend expanded outwards into rural areas.

In many areas of Scandinavia, coinage followed in the wake of weighed silver, although this often took quite some time and was certainly not universal. In most cases, the adoption of coinage followed peaceful contact with areas which were more familiar with its use. The production of coinage was the last stage in this process across much of Scandinavia and was somewhat sporadic for some time. Throughout the period, it was unlikely that users would have been handling locally produced money; a well-struck local coinage remained the exception rather than the rule. Rarer still was the exclusion of foreign currency and periodic renewal of the local coinage. However, this did not stop the widespread use of silver, and then coinage, as a means of exchange.

57 See hoard summary in Blackburn and Jonsson, "The Anglo-Saxon and Norman element"; and Gullbekk, "Renovatio monetae".

$5^{8}$ Gullbekk, Pengevesenets fremvekst, pp. 6o-65; and Gullbekk, Norges myntvesen.

59 Heijne, "Viking-age coin finds from south Scandinavia".

6o It is best summarized in Williams, "Silver economies, monetisation and society".

61 Sheehan, "The form and structure of Viking age hoards"; Blackburn, "Currency under the Vikings"; and Bogucki, "The use of money in the Slavic lands".

62 Skre, "Dealing with silver". 


\section{Feast and Famine}

The relative abundance or lack thereof of coinage throughout much of this period can be connected to the volumes of silver available to be struck. ${ }^{63}$ There remained a strong connection between newly discovered or exploited silver mines and significant coinages. The converse was also the case with dwindling coinages - in absolute numbers, weight or fineness - connected to periods of "silver famine", when the precious metal was difficult to acquire. In each case, it is difficult to quantify the relative abundance of silver across Europe, as the many differing coinages struck and the amount of silver in non-numismatic forms complicate matters. However, with these caveats in mind, it is possible to trace some of the trends.

From the outset of the period, significant mints associated with mines can be found, such as the very large coinage struck at Melle in France during the Carolingian and later period. ${ }^{64}$ Rising from obscurity in an earlier period, Melle's mints became among the most important in the entire Carolingian empire. Indeed, the name of the town - derived from the Latin metallum, meaning mine - speaks of the importance of the silver below the ground. Coins of Charlemagne and Louis the Pious picture the implements to produce coinage surrounded by the name of the town. ${ }^{65}$ The silver from Melle's mines influenced the circulating currency, as demonstrated by hoards from across the Carolingian empire which contain very significant numbers of Melle coins. ${ }^{66}$ Indeed, the general volume of currency across the various Carolingian mints increased in line with Melle's production and it is likely that the resources for this rise were found in the mines beneath the town.

However, perhaps the most significant exploitation of silver occurred in the late 1oth century and early nth centuries, centred upon the Harz Mountains in the kingdom of Germany ${ }^{67}$ Historical references record the discovery of a silver mine during the 96 os but it was only a generation later, during the reign of Otto III in the 99os that production of large numbers of silver coins commenced. The amount of silver mined was large; it represented the largest new source in early medieval Europe. Tenth-century texts suggest that up to $400 \mathrm{~kg}$ may have been mined in a single year. ${ }^{68}$ With an average coin weight of around

\footnotetext{
63 Spufford, Money and Its Use.

64 Grierson and Blackburn, Medieval European Coinage, pp. 235-40; and Coupland, "The use of coin", p. 282.

65 Coupland, "Carolingian single finds", p. 308.

66 Ibid., pp. 308-9.

67 Spufford, Money and Its Use, pp. 74-105; and Blanchard, Mining, pp. 566-74.

68 Blanchard, Mining, Metallurgy, and Minting in the Middle Ages, p. 566.
} 
$1.5 \mathrm{~g}$ this was equivalent to hundreds of thousands of new coins in circulation every year.

Much of this new silver was transformed into coins which are usually known as "Otto Adelheid pfennige", named after Otto III and his regent in the period 991-995, Empress Adelheid (Figure 5.3). Many of their coins were struck at the mint local to the mines, Goslar. The scale of silver mining was such that it spread over the following decades and led to the establishment of a number of mints. In the area to the east of the Rhine, coinage was struck only sporadically and in small numbers until the mid-1oth century ${ }^{69}$ The new silver saw the creation of a network of over 8 o mints stretching east across Germany to the Elbe, spreading outwards from the mines which were key to this process. ${ }^{70}$ This meant that coinage was used in areas where it had previously been scarce, and on a scale that would have been unthinkable a century before.

The very large volumes of currency from the mines of Saxony also found their way across Europe. Coins flowed in large numbers to the east and north, where they have been found in significant numbers in hoards. More than 90,00o German coins have been found across Scandinavia, where the hoard evidence suggests that they dominated the circulating currency in certain areas. ${ }^{71}$ In other parts of Europe it is slightly more challenging to trace the flow of silver, as German silver was minted into the local form upon arrival. In England, analysis of the metallic composition of coins suggests that very quickly after exploitation of the mints began, the chemical signatures of England's coinage switched to match that of German mines. ${ }^{72}$ The number of English coins in circulation also increased at this time, as evidence by a tripling of the number of single-finds dating from the second half of the 1oth century. ${ }^{73}$

Although large-scale coinages could be produced during periods of relative plenty, there were also periods during which silver was scarce, often referred to as silver famine. The output from the German mines was large but short-lived, declining dramatically in the middle of the 11th century. Without new sources of ore, silver became scarcer as a means of exchange. There were differing responses to this challenging set of circumstances. In Saxony, which had seen large outputs of coins from the 99os, the coinage ceased in the 1040s. This was not unusual: a number of German mints reduced their outputs drastically or

69 The best summary of this period in English remains Spufford, Money and Its Use in Medieval Europe, pp. 74-82.

$70 \quad$ Ibid., p. 76.

71 Ibid., p. 81.

72 Metcalf and Northover, "Interpreting the alloy of the later Anglo-Saxon coinage", p. 47.

73 Naismith, "The English monetary economy", p. 203. 


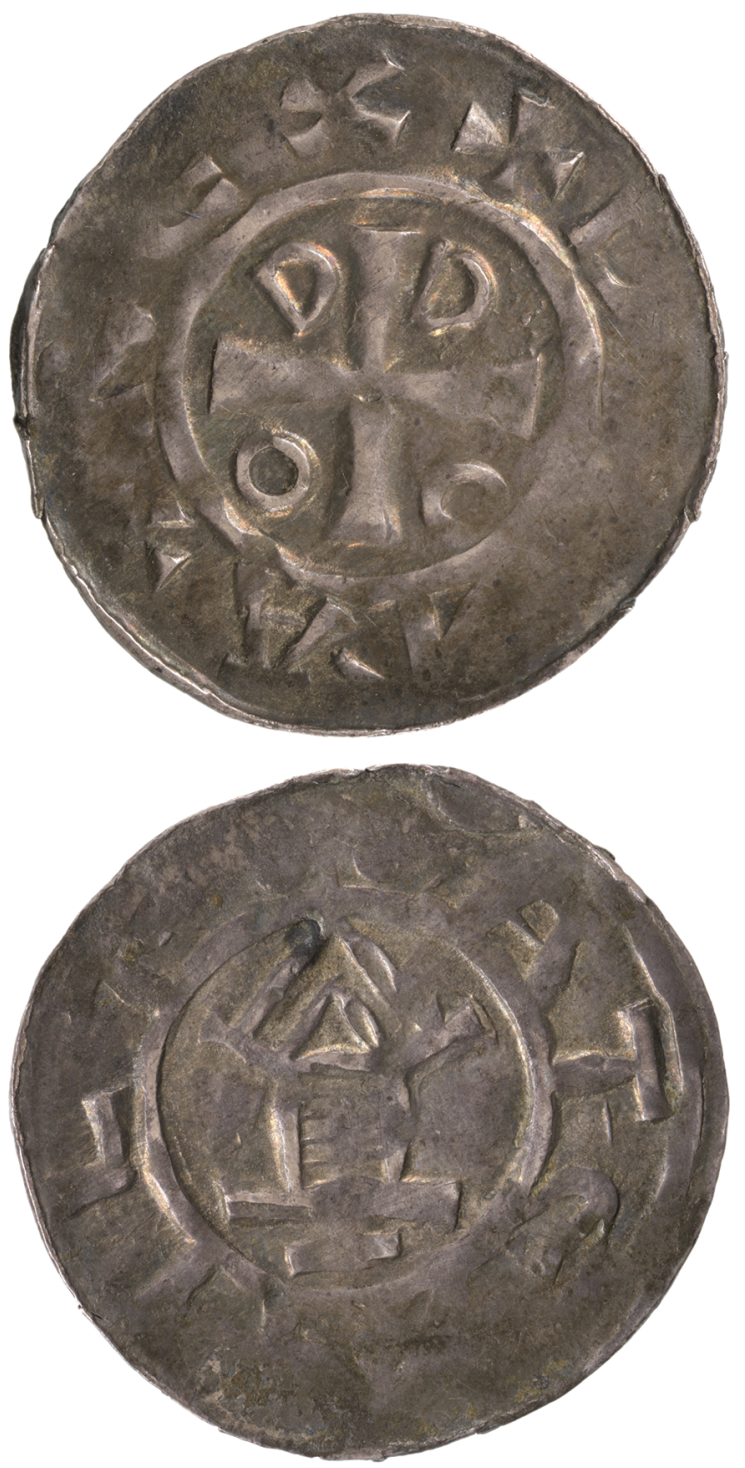

FIGURE 5.3 Silver “Otto-Adelheid” penny. CM.PG.610o-20o6. SOURCE: (CTHE FITZWILLIAM MUSEUM, CAMBRIDGE.

ceased entirely at that point. ${ }^{74}$ These effects can be traced across much of Europe. In England, where some quantification is possible, it can be argued that there was approximately half the volume of circulating silver at the end of the

74 Spufford, Money and Its Use, pp. 95-96. 
11th century than there had been at the beginning. ${ }^{75}$ In general, fewer coins were being struck at a smaller number of mints across Europe.

In other areas, there were attempts to make the smaller amounts of silver stretch further through debasement of the coinage. This occurred in two ways: some coins were struck to a much lighter standard, while in others the fineness of the alloy was reduced. In Rouen in northern France, the weight of the coinage declined from $c .1 .20 \mathrm{~g}$ to $c .0 .70 \mathrm{~g}$ between the 1oth and 11th centuries, a pattern matched at many other mints in northern Europe. ${ }^{76}$ There was also a tendency for the alloy to be diluted with non-precious metals. In Northern Italy, coins were struck with almost no silver content, a pattern replicated at the other end of Europe in Norway, where in the mid-11th century Harald Hardråde oversaw a reduction of his coinage's fineness by two-thirds. ${ }^{77}$

The dearth of silver into the early years of the 12th century may have contributed to the emergence of "bracteates" (Figure 5.4)..$^{78}$ These were incredibly thin coins which often had quite elaborate imagery but utilized only small amounts of silver. They can be construed as a pragmatic approach to coinage, continuing production and ensuring the mass dissemination of appropriate political and ecclesiastical imagery in the face of dwindling supplies of silver. They appear to have originated in the monastery of Pegau in Saxony around 1115 but came to be struck across much of eastern Europe during the 12th century. ${ }^{79}$ A strikingly similar phenomenon was occurring in Ireland, where the shortage of silver prompted the Dublin mint to first reduce the weight of its coinage, then to strike bracteates and gradually reduce their coins' fineness. ${ }^{80}$ While the responses varied, the evidence is strongly suggestive of a "silver famine" in Europe during the late 11th and early 12th centuries.

Between the 8th and 12th centuries the volume of currency was closely connected to the presence or absence of the raw materials used for production. Where new silver sources were found, this had a noticeable effect upon the volumes of coinage, both how much was struck and the numbers circulating. This spread relatively quickly from the source to other areas within and beyond the immediate region. This suggests active routes for the movement of silver and an important role for it in both regional and international exchange.

\footnotetext{
75 Allen, "The volume of the English currency, c.973-1158".

$7^{6}$ Spufford, Money and Its Use, pp. 102-3.

77 Spufford, Money and Its Use, p. 103; Skaare, Coins and Coinage in Viking-Age Norway, 9$11,79-85$.

78 Good summaries of the bracteate coinage in English are challenging to find, but a recent book has summarized the current state of research: Svensson, Renovatio monetae.

79 Ibid., pp. 63-65.

8o Dolley, Sylloge of Coins of the British Isles.
} 


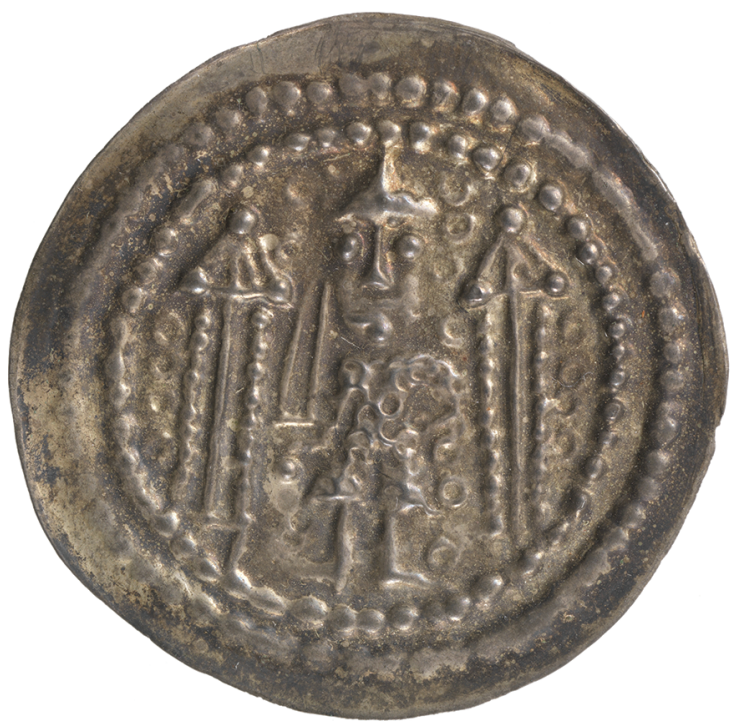

FIGURE 5.4 Silver bracteate of Conrad I of Meissen (1130-1156). CM.PG.11405-2006. SOURCE: (C)THE FITZWILLIAM MUSEUM, CAMBRIDGE.

There appear to have been near continent-wide shortages of precious metal that were felt particularly acutely in the late 11th and early 12th century. These provoked a range of reactions, in which it is possible to see some of the significant changes Europe had undergone between the 8th and 12th centuries. In areas of eastern Europe and Scandinavia which had little previous history of coined money, the response to the challenge of decreasing silver availability was not to give up on coinage but to try to eke out the supply as far as possible. It can be argued that coinage had become a part of the means of exchange within Europe, one which was not easily abandoned even when the raw materials required to strike it were becoming increasingly rare.

\section{Coinage and Authority}

Coinage represented a medium with enormous political potential; an official object that was mass-produced and could convey symbolic meaning through its combination of text and image. It was exploited by many medieval rulers who recognized these possibilities. That the very act of striking coinage was seen as regal enhanced its potential significance. A number of monarchs used their coinage and its iconographic potential to their advantage. Offa, for 
example, an English contemporary of Charlemagne, created a spectacular array of coins which included those which intended to represent the king in the form of a new Constantine I the Great. ${ }^{81}$

However, while the right to strike coinage was generally taken as a royal prerogative throughout the period, it was one which was also granted, in certain cases more willingly than others, to significant secular figures or to religious institutions. In the case of the former, the "feudal" coinage which emerged in 1oth-century France is a prime example. ${ }^{82}$ While the king retained authority for the striking of coinage, the privilege of minting devolved to many counts throughout the kingdom. The nature of this devolved authority took different forms and usually involved the count taking some or all the profits in exchange for producing the coinage. Some counts were granted further jurisdiction to prosecute those who contravened monetary laws. In many cases, these privileges were gradually extended or usurped, leading to the emergence of distinctive local coinages. Initially, many of these were issued anonymously, referring only to their place of origin or continuing to use older designs. ${ }^{83}$ Only later, as the counts became more certain of their own power, did they begin to issue coinage in their own names, rather than that of the king.

In the middle years of the 1oth century under the dukes William Longsword (c.927-945) and his son Richard I (c.942-996), Normandy struck its own coinage. ${ }^{84}$ This abandoned the name of the king in favour of that of the local ruler. This was an important step, one which other magnates across France followed relatively swiftly. The Fecamp hoard, hidden in Normandy during the 98os, includes coins struck at more than 30 different mints and acknowledging a range of different issuing authorities. ${ }^{85}$ The hoard also highlights the fact that coinage of several differing types issued by several different authorities circulated side by side. Other hoards from Normandy also have a mix of differing types, suggesting only a limited ability to ensure that local coinage was used in preference to others. ${ }^{86}$ Limitations on the extent of control are also visible on the explicitly royal currency, the production of which was almost entirely focused on Paris and the areas immediately surrounding it by the mid-to-late 1oth century.

81 Naismith, Money and Power in Anglo-Saxon England, pp. 54-64.

82 A geographic survey of the coinage is provided by Mayhew, Coinage in France from the Dark Ages to Napoleon, pp. 19-58.

83 Spufford, Money and Its Use, pp. 55-59.

84 Moesgaard, "A survey of coin production and currency in Normandy", pp. 111-14.

85 Spufford, Money and Its Use, p. 58.

86 Moesgaard, "A survey of coin production and currency in Normandy", pp. 116-17. 
The coinage had become very different from that established under Charlemagne more than a century earlier, with the changing nature reflecting the growth of the counts' power in relation to the king. However, even while it seldom named the reigning monarch, the right to issue it was always seen as a royal prerogative. While counts added their own names to coins, it was only after they had been granted the rights to mint them by the king.

Perhaps even more common than secular minting was coinage struck with or by ecclesiastical authorities. High-ranking churchmen - archbishops and bishops - or religious institutions were responsible for much coinage during this period. The nature of their involvement varied in many of the same ways that it did with secular figures. One of the most spectacular examples of the cooperation between ecclesiastical and royal authority can be found on the coinage of 1oth-century York. ${ }^{87}$ The town was conquered by a Viking army in the 86os, who took control and ruled it until 954. Before their arrival York had been the economic heart of the northern English kingdom of Northumbria, with a very extensive coinage. It was also the seat of an archbishop. The incoming Scandinavians replaced the secular authority in the town, but the archbishop remained, perhaps surprisingly given the fact that the new kings were "pagan".

The kings of this new dynasty struck coinage in York from the 89os onwards and for the following 6o years created a series of coins with rich Christian religious symbolism..$^{8}$ The earliest examples laid out the obverse legend, CNVT $\mathrm{REX}$, in a complex manner, requiring the reader's eyes to make the sign of the cross to interpret it (Figure 5.5). A variety of crosses are used on the coinages of York, including some with Byzantine parallels. Coinage struck c.905-919 utilizes the name of St. Peter in preference to that of the king. Its iconography is largely unparalleled among contemporary English currency. That it should emerge in York with Scandinavian rulers who originated in areas where both the use of coinage and the Christian faith would have been unusual is remarkable. This fact has contributed to a debate as to whether these coins represent the output of the king or archbishop within the town..$^{89}$ It is difficult to be definitive with many of the anonymous coins, but it does seem apparent that the archbishop had an important role in their production even if the coinage was struck under royal authority. This would fit with patterns which had previously existed, where coinages had been struck naming both king and archbishop. In this case, the archbishop clearly had a role in the iconographic choices and quite possibly the administration of the coinage.

87 Blackburn, "The coinage of Scandinavian York".

88 Ibid., pp. 329-35.

89 See discussion in Gooch, "The swordless St Peter coinage of York". 
In other cases, the right to strike coinage was granted more completely to religious institutions. This is very clear in Germany, where many institutions struck their own coins in the 1oth and 11th centuries. These were overwhelmingly religious in nature, with 166 charters bestowing minting rights, over 90
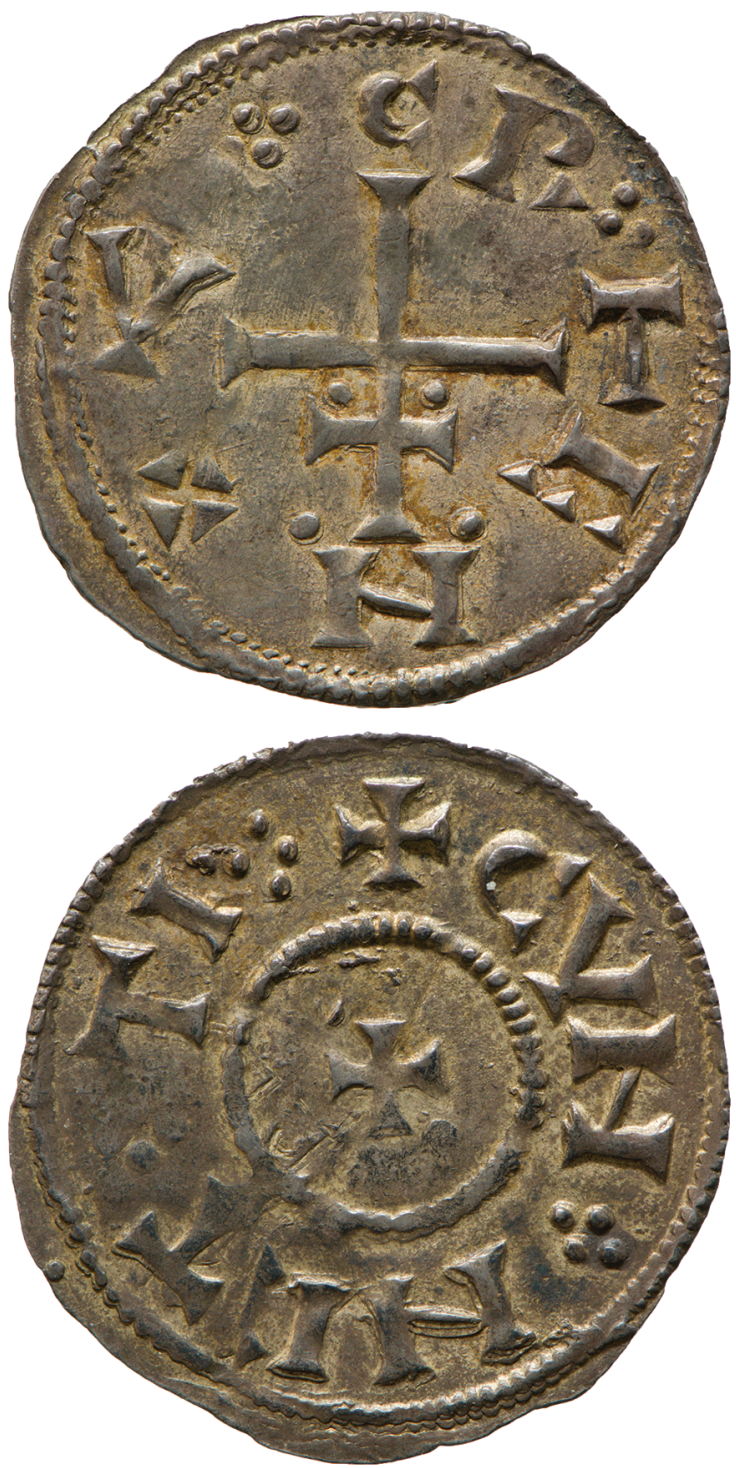

FIGURE 5.5 Silver penny of King Cnut (c.900), York. YORYM:200o.6o7. SOURCE: (CYORK MUSEUMS TRUST. 
per cent of these granted to either episcopal or monastic institutions..$^{90}$ It is of some importance to distinguish between the two, as monastic coinages were much more directly accountable to the king than were the episcopal. In chronological terms, early grants occurred in the gth century - the first was to Corvey Abbey in 833 - but it was during the 1oth century, particularly the reign of Otto III, that significant numbers of grants occurred. ${ }^{91}$ In general, most of the 40 Ottonian mints in Saxony which opened during this period were ecclesiastical rather than secular or royal. ${ }^{92}$ The expansion of minting to religious institutions also resulted in a move away from acknowledging royal authority on coinage. Mints which had previously struck coinage depicting the king, either with or without a corresponding bishop, focused increasingly upon episcopal iconography, naming saints or archbishops. This is visible on the coinage of Cologne, which struck royal coinage until the death of Henry II in 1024. ${ }^{93}$ Following his death, the coinage named both the king and the archbishop of Cologne; the name of the king was abandoned entirely over the coming decades.

Throughout the whole of the period in question the right to strike coinage was a royal prerogative. This was a right which could, and often was, granted to others, allowing a variety of secular and ecclesiastical persons to become involved in the process of producing and administering money. The extent to which authority was relinquished varied hugely, mirroring the diverse range of relationships enjoyed between kings and their subjects. Coinage could be highly centralized, administered by royal authority and with regal imagery. Conversely, authority could be granted almost entirely to another, including the right to strike, to take profits, and to determine iconography. Much of Europe fell between one of these two extremes, but it should be acknowledged that the former, a highly centralized coinage, was the exception rather than the rule in this period.

\section{Monetization}

One of the preoccupations of scholars studying this period has been "monetization". A single definition of the term is elusive, but arguments usually focus around the volume of currency in circulation, how frequently it was used, for

\footnotetext{
90 Steinbach, "From HEINRICVS REX to ROTHARDVS ABbas", p. 187.

91 Ibid., pp. 186-87.

92 Spufford, Money and Its Use, pp. $76-77$.

93 Grierson, The Coins of Medieval Europe, p. 66.
} 
what purposes, and by whom. This has fed into wider debates about the role of commerce within medieval society, as opposed to more socially motivated exchange. ${ }^{94}$ The issue has provoked debate in many contexts, with the period seen at times as one where "natural economy" - emphasizing an agrarian and non-commercial economy - dominated, with a "money economy" peripheral. ${ }^{95}$ Trying to determine when Europe became monetized and shifted from a natural to a money economy has proved an unhelpful approach and it seems increasingly accepted that it was a variable phenomenon which occurred differently across Europe. A more nuanced approach, accepting that coinage could be used in different ways by different people and in differing amounts, is increasingly at the forefront of research. Furthermore, the idea that monetization is a "process" by which an ever-expanding number of people used coinage is unhelpful and can actually obscure periods where coin use declined or altered.

With these caveats in mind, it must be stressed that during this period the use of silver for exchange, particularly in coin form, became much more common. The form of this silver, in its coined or uncoined state, varied hugely across the period. It was used in more places, for a greater range of transactions, and by a larger number of people in 115 o than it had been around 75 . However, it is highly unlikely that silver, in any form, ever represented the means of exchange in a majority of transactions. Whilst it was clearly of some importance, it is imperative to remember that it also represents the most archaeologically visible means of exchange.

One of the important aspects of research on monetization has been a focus on the volumes of currency struck. In simple terms, the greater the number of coins in circulation, the more common a means of exchange they represent. In England, there have been attempts to quantify the volumes of coinage for many decades. ${ }^{96}$ These estimates are usually based upon a statistical estimate of the number of dies used to strike any given coin type, multiplied (usually by the slightly arbitrary figure of 10,00o) to give an approximate number of coins originally struck. There are wide margins of error within this process, but the figures give an indication of the scale of coinage struck and are most effective when applied consistently over a given period to model changing scales of minting through time. Estimates in England have suggested that thousands

\footnotetext{
94 Cf. Dagfinn Skre's contributions in Skre, Means of Exchange.

95 The classic debate, surrounding the Carolingian coinage, is summarized in Coupland, "The use of coin in the Carolingian empire", pp. 259-62; See also Gullbekk, "Monetisation in medieval Scandinavia".

96 See discussion in Allen, "The volume of the English currency, c.973-1158".
} 
of dies were used to produce tens of millions of coins during the late 1oth and early 11th centuries..$^{97}$ These figures are significant and suggest that coinage was more common than we might envisage from the relatively small volume of modern finds. However, they pale in comparison to later periods, particularly from the 13th century when coinage was struck on a scale inconceivable two centuries earlier. ${ }^{98}$

If the volume of currency represents one aspect of discussion around monetization then the other evidence is connected to the intensity of use, or velocity of circulation. Estimates of this usually rely upon the evidence of "single-finds", coins found individually during archaeological excavation or by chance. It is assumed that the single coins are most likely to have been lost during exchange, with more finds suggestive of a greater number of exchanges using coinage. In England, understanding of the use of coinage has been transformed in the past 40 years as metal-detectorists have found thousands of coins, transforming the amount of evidence available and interpretations of money. ${ }^{99}$ This has allowed a much more nuanced picture to emerge, highlighting chronological and geographical patterns. In the case of the former, the 8th century emerges as a peak for the use of currency, followed by a severe decline during the 9 th. An increase towards the end of the 1oth century is very clear, the many coins of the second half of the century presenting a clear contrast to what had gone before. ${ }^{100}$

To move beyond the general trends that can be discerned from the singlefinds into the more specific issues of who used money and how requires the integration of historical evidence. At a simple level, this can give a sense of its relative buying power. For example, Carolingian references discuss the buying power of the 8th-century penny: one would have purchased 12 loaves of bread and four a sheep or pig, while in the early gth century 360 silver coins would have been enough to purchase land. ${ }^{101}$ However, to move into a more nuanced impression is challenging, as the view of coin use given by the historical and archaeological evidence is at best complementary, and occasionally seemingly contradictory. It requires careful interpretation to understand how and why different impressions of the use of money and coinage emerge. Rory Naismith's work on the charter evidence from England has skilfully brought together charters to allow comparison with the single-find data. ${ }^{102}$ These offer

\footnotetext{
97 Ibid., pp. 493-94.

98 Allen, "The volume of the English currency, 1158-1470".

99 Naismith, "The English monetary economy".

100 Ibid., pp. 202-4; cf. Allen, "The volume of the English currency, c.973-1158".

101 Coupland, "Charlemagne's coinage", pp. 212-13.

102 Naismith, Money and Power in Anglo-Saxon England, pp. 267-73.
} 
a level of detail - who, when, where, why, and how much - that is invaluable, although with the caveat that most concern transfers of land, an exceptional rather than typical type of transaction. The picture that emerges is one where boundaries between "gift" or socially-motivated exchange and commercial exchange are very blurry. Furthermore, precious metal features heavily as a means of exchange although silver coins specifically are relatively rarely mentioned. This leads to the conclusion that their use was not particularly appropriate for land purchase and implies a more mundane use below the elite level which the historical evidence typically describes.

Trying to reconcile these varying approaches, it does seem that there were substantial falls in the amounts of money in use in England, particularly in the late 8th century and, to a lesser extent, in the later 11th. There were also significant rises in the scale of coin use, particularly in the late 1oth century. The changing number of finds from these periods is closely matched by the volumes of production, suggesting that as the number of coins increased, so did the level of use. The historical evidence would suggest that these coins were not just used for elite transactions; indeed, the charters would suggest that they were not appropriate for the purchase of land. They are likely to represent currency used by people slightly further down the social scale who utilized them in transactions which did not primarily revolve around gift exchange. Even in the periods when there were relatively few coins circulating, it appears that coinage was not completely restricted, but was used by a range of people within the English economy. However, even at times when coin use was at its highest, perhaps in the years following 10oo, it is unlikely that it ever fulfilled a very widespread role. Coin finds from either the late Roman or the High Medieval period completely dwarf those from this period, suggesting that any case in favour of extensive monetization must remain cautious.

\section{Summary}

Attempting to summarize the period in question is a challenge, given the varied political situations across the expanse of Europe and the quite different ways in which coinage was used at the beginning. Nonetheless, it is possible to draw a few broad trends. The first is that the period saw the emergence of the silver penny - thin, broad, and with the possibility of complex iconography across Europe. During the height of the Carolingian empire, more of Europe was using a single type of coinage than had done so at any point since the fall of the western Roman empire. Even beyond the limits of the Carolingian 
empire the silver penny was adopted, becoming the norm across Europe even in areas with little previous history of coin use. Silver pennies drove out other forms of money, creating a more homogenous means of exchange across the continent. This homogeneity would probably have been at its peak shortly after the year 1000 when the fundamental medium would have been quite familiar across almost all of Europe even if the specific imagery used on the coins varied enormously.

The second trend is that a growing number of people and institutions became involved in the expanding volume of silver production. Throughout all of the early medieval period, the right to strike coinage remained a royal prerogative. However, many kings across Europe granted these rights to other people and institutions, both ecclesiastical and secular. Some merely administered the coinage on behalf of the king while others struck coins in their own names. This phenomenon became more common during this period, with the production of coinage expanding from a handful of kings in the 8th century to literally hundreds of others over the course of the following three centuries.

The various issuing authorities contributed to the responses to the dwindling supplies of silver that Europe experienced around 1100. A clear "silver famine" resulted in reductions in coin weight, fineness, and absolute numbers. This highlights the fact that the supplies of money in Europe at the time were reliant upon the availability of raw material: supplies of bullion were the key to determining the availability of precious metal monies, and the peaks and troughs of bullion supply were matched by production.

Last, more people in Europe were utilizing coinage in the year 1150 than had been in 750. While this statement conceals huge amounts of chronological and geographical variation, it holds broadly. Many new areas of Europe beyond the boundaries of the old Roman empire were using coinage, often for the first time. Levels of coin production recovered from a nadir in the 9th century, suggesting steady increases thereafter. These are matched by growing numbers of finds: that is, more coinage was being used by more people for an ever greater range of transactions. While it is unlikely this was ever anything like a majority of people or most transactions, in certain contexts (particularly towns and ports), coinage would not have been exceptional or unusual. Perhaps most tellingly, the approach to the dwindling silver supplies of the 12th century was not simply to give up on coinage and revert to other media of exchange, but to stretch the silver as far as possible, striking light and debased coins or bracteates. This implies that a coin-using mentality was well entrenched across much of Europe; a point which is much more difficult to make for the 8th century. 


\section{Bibliography}

Allen, M.R., "The volume of the English currency, c.973-1158", in Cook and Williams, Coinage and History in the North Sea World, 487-523.

Allen, M.R., "The volume of the English currency, 1158-1470", The Economic History Review 54(4) (2001), 595-611.

Biddle, M., "Xpictiana Religio and the tomb of Christ", in Naismith, Allen, and Screen, Early Medieval Monetary History, 115-44.

Blackburn, M.A.S., "The coin finds", in Skre, Means of Exchange, 29-74.

Blackburn, M.A.S., "The coinage of Scandinavian York", in R.A. Hall (ed.), Aspects of Anglo-Scandinavian York, York, 2004, 325-49.

Blackburn, M.A.S., "Currency under the Vikings, part 3: Ireland, Wales, Man and Scotland", British Numismatic Journal 77 (2007), 119-49.

Blackburn, M.A.S., "Gold in England during the 'age of silver' (eighth-eleventh centuries)", in Graham-Campbell and Williams, Silver Economy in the Viking Age, 55-98.

Blackburn, M.A.S., "Money and coinage", in The New Cambridge Medieval History vol. II, Cambridge, 2005, 538-59.

Blackburn, M.A.S., "The Viking winter camp at Torksey, 872-3", in Viking Coinage and Currency in the British Isles, London, 2011, 221-64.

Blackburn, M.A.S., and Jonsson, K., "The Anglo-Saxon and Norman element of north European coin finds", in M.A.S. Blackburn and D.M. Metcalf (eds.), Viking-Age Coinage in the Northern Lands, vol. 1, Oxford, 1981, 147-255.

Blanchard, I., Mining, Metallurgy and Minting in the Middle Ages. Vol. 1: Asiatic Supremacy, 425-1125, Stuttgart, 2001.

Bogucki, M., "The beginning of dirham import to the Baltic Sea zone and the question of early emporia", in U. Lund Hansen and A. Bitner-Wróblewska (eds). Worlds Apart?: Contacts across the Baltic Sea in the Iron Age, Copenhagen, 2010, 351-61.

Bogucki, M., "The use of money in the Slavic lands from the ninth to eleventh century: the archaeological/numismatic evidence", in Graham-Campbell, Sindbæk, and Williams, Silver Economies, Monetisation and Society in Scandinavia, 133-51.

Cook. B., and Williams, G. (eds). Coinage and History in the North Sea World: Essays in Honour of Marion Archibald, Leiden, 2006.

Coupland, S., "Carolingian single finds and the economy of the early ninth century", The Numismatic Chronicle 170 (2010), 287-319.

Coupland, S., "Charlemagne's coinage: ideology and economy”, in J. Story (ed). Charlemagne: Empire and Society, Manchester, 211-29.

Coupland, S., "Money and coinage under Louis the Pious", Francia 17(1) (1990), 23-54.

Coupland, S., "The portrait coinage of Charlemagne", in Naismith, Allen, and Screen, Early Medieval Monetary History, 145-56. 
Coupland, S., "The use of coin in the Carolingian Empire in the ninth century", in Naismith, Allen, and Screen, Early Medieval Monetary History, 257-93.

Dolley, M., Sylloge of Coins of the British Isles, Vol. 8: Hiberno-Norse Coins in the British Museum, London, 1966.

Gannon, A., The Iconography of Early Anglo-Saxon Coinage: Sixth to Eighth Centuries, Oxford, 2014.

Garipzanov, I., "The image of authority in Carolingian coinage: the image of a ruler and Roman imperial tradition", Early Medieval Europe 8(2) (1999), 197-218.

Gelichi, S., and Hodges, R. (eds.), From One Sea to Another: Trading Places in the European and Mediterranean Early Middle Ages: Proceedings of the International Conference Comacchio, 27th-2gth March 2009, Turnhout, 2012.

Gooch, M., "The swordless St Peter coinage of York, c.905-c.919", in Naismith, Allen, and Screen, Early Medieval Monetary History, 459-70.

Graham-Campbell, J., Sindbæk, S.M., and Williams, G. (eds.), Silver Economies, Monetisation and Society in Scandinavia, AD 80o-110o, Aarhus, 2011.

Graham-Campbell, J., and Williams, G. (eds.), Silver Economy in the Viking Age, Walnut Creek, Cal., 2010.

Grierson, P., The Coins of Medieval Europe, London, 1991.

Grierson, P., "The gratia Dei Rex coinage of Charles the Bald", in M. Gibson and J.L. Nelson (eds.), Charles the Bald: Court and Kingdom, Oxford, 1981, 52-64.

Grierson, P., "Numismatics and the historian", Numismatic Chronicle 2 (1962), i-xiv.

Grierson, P., and Blackburn, M.A.S., Medieval European Coinage, Vol. 1: The Early Mid-

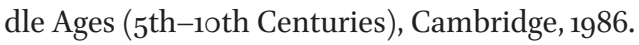

Gullbekk, S.H., "Coinage and monetary economies", in S. Brink and N. Price (eds.), The Viking World, London, 2008, 159-69.

Gullbekk, S.H., "Monetisation in medieval Scandinavia", in N. Holmes (ed.), Proceedings of The XIVth International Numismatic Congress Glasgow 2009. Vol. 2: 1458-1464, London, 2011.

Gullbekk, S.H., Norges myntvesen i tidlig middelalder: organisering av myntvesenet og myntenes funksjon, Oslo, 1994.

Gullbekk, S.H., Pengevesenets fremvekst og fall i Norge i middelalderen, Copenhagen, 2009 .

Gullbekk, S.H., "Renovatio monetae i Norge i middelalderen", Nordisk Numismatisk Årsskrift (1992), 52-87.

Gustin, I., "Coin stock and coin circulation in Birka", in Graham-Campbell, Sindbæk, and Williams, Silver Economies, Monetisation and Society in Scandinavia, 227-44.

Hårdh, B., Silver in the Viking Age: A Regional Economic Study, Stockholm, 1996.

Heijne, C. von, "Viking-age coin finds from south Scandinavia", in Graham-Campbell, Sindbæk, and Williams, Silver Economies, Monetisation and Society in Scandinavia, $185^{-202 .}$ 
Hilberg, V., "Silver economies of the ninth and tenth centuries AD in Hedeby", in Graham-Campbell, Sindbæk, and Williams, Silver Economies, Monetisation and Society in Scandinavia, 203-26.

Jensen, J.S., Danish Coins from the 11th Century in the Royal Collection of Coins and Medals, Copenhagen, 1995 .

Jonsson, K., "Sweden in the tenth century: a monetary economy?", in GrahamCampbell, Sindbæk, and Williams, Silver Economies, Monetisation and Society in Scandinavia, $245^{-58}$.

Kilger, C., "Hack-silver, weights and coinage: the Anglo-Scandinavian bullion coinages and their use in late Viking-age society", in Graham-Campbell, Sindbæk, and Williams, Silver Economies, Monetisation and Society in Scandinavia, 259-80.

Kilger, C., "Kaupang from afar: aspects of the interpretation of dirham finds in northern and eastern Europe between the late 8th and early 1oth centuries", in Skre, Means of Exchange, 199-252.

Malmer, B., "South Scandinavian coinage in the ninth century", in Graham-Campbell and Williams, Silver Economy in the Viking Age, 13-27.

Mayhew, N., Coinage in France from the Dark Ages to Napoleon, London, 1988.

Metcalf, D.M., "Inflows of Anglo-Saxon and German coins into the northern lands c.997-1024: discerning the patterns", in Cook and Williams, Coinage and History in the North Sea World, 349-88.

Metcalf, D.M., "Introduction", in D.M. Metcalf (ed.), Coinage in Ninth-Century Northumbria: The Tenth Oxford Symposium on Coinage and Monetary History, Oxford, $1987,1-10$.

Metcalf, D.M., and Northover, J.P., "Interpreting the alloy of the later Anglo-Saxon coinage", British Numismatic Journal 56 (1986), 35-63.

Moesgaard, J.C., "The Grisebjerggård hoard and the beginning of pecking”, in GrahamCampbell, Sindbæk, and Williams, Silver Economies, Monetisation and Society in Scandinavia, 297-308.

Moesgaard, J.C., "The import of English coins to the northern lands: some remarks on coin circulation in the Viking Age based on new evidence from Denmark", in Cook and Williams, Coinage and History in the North Sea World, 389-434.

Moesgaard, J.C., "A survey of coin production and currency in Normandy, 864-945", in Graham-Campbell and Williams, Silver Economy in the Viking Age, 99-121.

Naismith, R., "The English monetary economy, c.973-1100: the contribution of singlefinds", The Economic History Review 66(1) (2013), 198-225.

Naismith, R., "Kingship and learning on the broad penny coinage of the "Mercian supremacy", in T. Abramson (ed.), Studies in Early Medieval Coinage 2: New Perspectives, Woodbridge, 2011, 47-6o.

Naismith, R., Money and Power in Anglo-Saxon England: The Southern English Kingdoms, 757-865, Cambridge, 2014. 
Naismith, R., Allen, M.R., and Screen, E. (eds). Early Medieval Monetary History: Studies in Memory of Mark Blackburn, Farnham, 2014.

Ostergren, M., "The Spillings hoard(s)", in Graham-Campbell, Sindbæk, and Williams, Silver Economies, Monetisation and Society in Scandinavia, 321-36.

Rovelli, A., "Coins and trade in early medieval Italy", Early Medieval Europe 17(1) (2009), 45-76.

Rovelli, A., "Some considerations on the coinage of Lombard and Carolingian Italy", in I.L. Hansen and C. Wickham (eds.), The Long Eighth Century, Leiden, 2000, 195-223. Sheehan, J., "The form and structure of Viking Age hoards: the evidence from Ireland", in Graham-Campbell and Williams, Silver Economy in the Viking Age, 149-61.

Skaare, K., Coins and Coinage in Viking-Age Norway: The Establishment of a National Coinage in Norway in the XI Century, with a Survey of the Preceding Currency History, Oslo, 1976.

Skre, D., "Commodity money, silver and coinage in Viking-age Scandinavia", in GrahamCampbell, Sindbæk, and Williams, Silver Economies, Monetisation and Society in Scandinavia, 67-92.

Skre, D., "Dealing with silver: economic agency in south-western Scandinavia AD 6oo1000 ", in Skre, Means of Exchange, 343-55.

Skre, D., ed., Means of Exchange: Dealing with Silver in the Viking Age, Aarhus, 2008.

Spufford, P., Money and its Use in Medieval Europe, Cambridge, 1988.

Steinbach, S., "From HEINRICVS REX to ROTHARdVS ABbAS: monastic coinage under the Ottonians and Salians (c.911-1125)", in G.E.M. Gasper and S.H. Gullbekk (eds.), Money and the Church in Medieval Europe, 1000-1200: Practice, Morality and Thought, Farnham, 2015, 185-96.

Svensson, R., Renovatio Monetae: Bracteates and Coinage Policies in Medieval Europe, London, 2013.

Wiechmann, R., "Hedeby and its hinterland: a local numismatic region", in GrahamCampbell and Williams, Silver Economy in the Viking Age, 29-48.

Williams, G., "Kingship, Christianity and coinage: monetary and political perspectives on silver economy in the Viking age", in Graham-Campbell and Williams, Silver Economy in the Viking Age, 177-207.

Williams, G., "Silver economies, monetisation and society: an overview", in GrahamCampbell, Sindbæk, and Williams, Silver Economies, Monetisation and Society in Scandinavia, 337-72.

Woods, A.R., "Monetary activity in Viking-age Ireland: the evidence of the single-finds", in Naismith, Allen, and Screen, Early Medieval Monetary History, 295-330. 